\title{
An Exploratory Examination of Propensity and Performance in New Venture Internationalization
}

\author{
Jay Hyuk Rhee
}

Compared to established firms' international expansion that is usually a result of the longer-term business planning and extension of domestic operations, new ventures' international expansion may show different patterns in many aspects. The purpose of this exploratory study is to investigate causes and consequences of internationalization launched by new ventures. This study derives several propositions based on theoretical arguments and empirically tests how relevant variables at different levels (product, strategy, and start-up team) may affect the propensity and the performance of international expansion. Overall results indicate the necessity of studying the two aspects of international entrepreneurship-propensity and performance-separately rather than as a single issue.

I nternational entrepreneurship has been identified as one of the important newly emerging thrusts of international business research (Wright and Ricks 1994). From the theoretical points of view, the phenomenon of international entrepreneurship, "new and innovative activities that have the goal of value creation and growth in business organizations across national borders" (McDougall and Oviatt 1997, 293), provides researchers in the field of international business with a valuable opportunity to revisit the issue of international expansion. ' Given the fact that most of the theoretical frameworks related to international expansion have been applied to and tested with such established firms as multinational corporations (MNCs) and small- and mediumsized enterprises (SMEs), the emergence of new ventures as a major player in the global economy enables researchers to investigate the validity of the frameworks in a new setting. In fact, the phenomenon of international entrepreneurship is in a sharp contrast with the traditional approach toward international expansion (McDougall, Shane, and Oviatt 1994). Emphasizing the uncertain nature of operating across national borders, the literature in the field of international business tends to propose an incremental approach toward international expansion.

As the terms, "accelerated internationalization" (Oviatt and McDougall 1997; Shrader, Oviatt, and McDougall 2000) and "born-global" (Hordes, Clancy, Baddaley 1995; Knight and Cavusgil 1996; Madsen and Servais, 1997) indicate, however, it is not unusual anymore that new ventures enter into a global market right after they are "born" or while they are still "new." By operating as a young orga- nization with a little history of operations, new ventures face the liability of newness (Stinchcombe 1965). By expanding abroad and operating in unfamiliar environments, they also face the liability of foreignness (Hymer 1976; Johanson and Vahlne, 1977). As a result, new ventures that expand abroad while they are still young may face a double-edged sword-the liabilities of newness and foreignness.

Even though it was identified as an important newly emerging research topic in as early as the mid-1990s (Wright and Ricks, 1994), international entrepreneurship has not yet been explored rigorously in existing literature. Many studies in the field of entrepreneurship broadened our understanding about determinants of new venture creations, but very few studies have investigated the growth and survival of new ventures in the international contexts (McDougall and Oviatt 1997; Zahra, Ireland, and Hitt 2000). Similarly, the literature on SMEs has reported considerable number of findings such as motives and barriers (Chen and Martin 2001; Karagozoglu and Lindell 1998), processes (Gankema, Snuif, and Zwart 2000; Zafarullah, Ali, and Young 1998) and strategies (Berra, Piatti, and Vitali 1995; Chetty and Holm 2000) of internationalization by SMEs. Given the significant differences in many aspects between SMEs and new ventures (Begley and Boyd 1987; Covin 1991; Stewart, Watson, Carland \& Carland 1998; Wortman 1986), however, the generalizations about the internationalization patterns derived from the literature on SMEs may be inappropriate when applied to new ventures.

Compared to established firms' international expansion that is usually a result of the longer-term business planning and extension of domestic operations (Chen and Martin 2001; Hood and Young 1979), new ventures' international expansion may show different patterns in many aspects. The purpose of this exploratory study is to investigate causes and consequences of international expansion undertaken by new ventures. More specifically, this research investigates the determinants of propensity to undertake international expansion and the performance of international expansion launched by new ventures. This study also investigates whether the determinants of propensity also affect their performance. Unlike previous studies dealing with new ventures that might have already been successful in weathering rough times (e.g., Shrader, Oviatt, and McDougall 2000), this study exclusively focuses on new ventures that are at their earlier stages. 
This article discusses the liabilities of newness and foreignness that new ventures face and develops propositions based on several theoretical perspectives. It then introduces the analytical method to test the propositions and reports empirical results. The final section of the article summarizes the findings and discusses their implications for future research on international entrepreneurship.

\section{Double-edged Sword of International Entrepreneurship}

Unlike such firms with a long history of operation as MNCs and SMEs, new ventures face certain internal and external problems or "liabilities of newness" (Stinchcombe 1965). Members in new ventures generally involve new roles, which are only learned by experience. Visible role models seldom exist in new ventures, and thus learning from former occupants of roles is not as feasible as in established firms. To overcome this problem, new ventures may have to invest in education, which requires high costs and leads to temporary inefficiency. One of the typical external problems that new ventures face is that they must rely heavily on social relations among strangers. The liabilities of newness will be especially higher in industries in which firms with a longer history of operation enjoy stronger ties with the people they serve. As organizations may progress through major stages of development facing different opportunities and challenges in each stage (Terpstra and Olson 1993), the liabilities of newness will also vary across new ventures depending on their stages of development. For example, using the sample of technology-based new ventures, Kazanjian (1988) found that the three dominant problems (sales/marketing, organization systems, and people) in the stage of growth were different in content and relative importance from those encountered during the stages of conception and commercialization. Focusing on fast-growing firms, Terpstra and Olson (1993) also found that firms faced different problems depending on whether they were at start-up or growth stages.

In addition to the liability of newness, new ventures may face "liabilities of foreignness" (Hymer 1976; Johanson and Vahlne 1977) when expanding their operations beyond domestic markets. Liabilities of foreignness arise from cultural, legal, institutional, and linguistic differences; lack of knowledge of local market conditions; , and increased expense in terms of communication and misunderstandings of operating at a distance. These liabilities are inherent disadvantages for firms operating in unfamiliar foreign markets, an assumption that has been largely unquestioned in developing theories of MNCs (Zaheer 1995). To offset such inherent disadvantages, MNCs must have some advantages not shared by their local competitors (Buckley and Casson 1976; Caves 1982; Dunning 1977; Hennart 1982). The impacts of the liabilities of foreignness will be much greater on new ventures than on such firms with a long history of international operation as MNCs. By relying on their integrated value-adding systems on a global basis and by exploiting economies of global scale or scope, MNCs may feel the liabilities of foreignness less (Zaheer 1995). However, such global network systems (Ghoshal and Bartlett 1990; Ghoshal and Nohria 1989) would be practically difficult, if not impossible, for new ventures to have developed during their earlier stages of development. It is also true that new ventures usually face greater liabilities of foreignness compared to SMEs that already have foreign operations (Chen and Martin 2001).

\section{Theoretical Arguments and Propositions}

New ventures should have some competitive advantages to overcome the double-edged sword of international entrepreneurship. What could be the sources of such competitive advantages that may enable new ventures to undertake international expansion and furthermore achieve higher levels of performance in international expansion? This study seeks to identify the sources of the competitive advantages from three levels: product, strategy, and start-up team. By comparing the three levels together, this study may also be able to identify among the three - "what" (product), "how" (strategy), and "who" (startup team)-the most important determinant of the causes and consequences of international entrepreneurship. In addition, this study seeks to compare the patterns of international expansion by new ventures with those by such established firms as MNCs or SMEs.

\section{Product Level}

Given the fact that one of the typical liabilities of newness is the lack of recognition about the product that a new venture aims to provide, competitive advantages for a new venture may partially depend on its ability to effectively deal with potential customers' brand loyalty. Consumers may be reluctant to switch to a new product, especially one provided by new firms (Porter 1980). One of the best approaches to overcome disadvantages stemming from brand loyalty is to provide a unique product. Higher levels of uniqueness will lower the heights of brand loyalty and thus help new ventures better avoid direct competitions with such established firms as MNCs and SMEs. As the perspectives based on the product life cycle theory (Vernon 1966, 1979) suggest, new ventures would be in a better position to undertake international expansion through exporting while the product keeps its unique characteristics. The uniqueness of the product will also enable new ventures to charge higher prices, which in turn leads them to achieve higher levels of performance.

Competitive advantages for a new venture may also stem from its ability to introduce multiple products. 
Diversified firms, in terms of the number of products they serve, may view international expansion as an attractive option to achieve economies of scope (Hitt, Hoskisson, and Kim,1997). As firms become increasingly product diversified, they may have to deal with too much information. However, early product diversification tends to focus on highly related product markets (Tallman and Li 1996). Thus, potential synergies and economies of scope related to product diversification may provide new ventures with an incentive to undertake international expansion and also enable them to achieve a higher level of performance in international expansion.

Proposition 1 (P1): Product uniqueness will be positively related to (1) the propensity to undertake international expansion and (2) the performance in international expansion.

Proposition 2 (P2): Product diversification will be positively related to (1) the propensity to undertake international expansion and (2) the performance in international expansion.

\section{Strategy Level}

Formulating and implementing proper generic strategies is essential in gaining and sustaining competitive advantages for survival and growth of firms regardless of whether they are new or established firms. Unlike the profusion of empirical work on the effect of strategy on competitive advantages of established firms, however, there has been only limited empirical work on that issue in the context of new ventures (e.g., Gartner, Starr, and Bhat 1998; Robinson 1998; Sandberg and Hofer 1987; Tyebjee and Bruno 1984).

New ventures may consider pursuing as many strategies as established firms do, but the feasibility and effectiveness of strategic choices would not be the same. For example, a cost-oriented strategy requires a firm to exploit the economies of scale, probably the most important source of cost advantages (Scherer 1980). It is usually an established firm that has the largest volume of production essential to exploit the economies of scale. In contrast, it would be rare that a new venture has the infrastructure and resources in place and sufficient demand for its product and services from the beginning (Allen 1999). Furthermore, maintaining cost advantages would be more difficult when undertaking international expansion may incur such additional costs as transportation and tariffs. Consequently, it would be less likely for new ventures that implement a cost-oriented strategy to be involved in international expansion through exporting, and it would be also difficult for those expanding abroad with a cost-oriented strategy to achieve higher levels of performance in their international expansion.

In contrast, it would be much effective for new ventures to implement strategies that can generate more than one winner. For example, new ventures may take new and advanced technologies as a source of competitive advantages to compete against established firms with a long history of operations. Unlike the cost-oriented strategy, technology-oriented differentiation strategies can help new ventures avoid head-to-head competitions with established firms in an industry (Gartner, Starr, and Bhat 1998; Sandberg and Hofer 1987). Thus, new ventures that implement a strategy exploiting new and advanced technologies would be in a better position to overcome the liability of foreignness and furthermore achieve higher levels of performance in international expansion.

Proposition 3 (P3): Cost-oriented strategy will be negatively related to (1) the propensity to undertake international expansion and (2) the performance in international expansion.

Proposition 4 (P4): Technology-oriented strategy will be positively related to (1) the propensity to undertake international expansion and (2) the performance in international expansion.

\section{Start-up Team Level}

According to the resource-based view of firms (Barney 1991; Rumelt 1984; Wernerfelt 1984), firm resources that are rare, valuable, nonsubstitutable, and imperfectly imitable form the basis for a firm's sustained competitive advantages. Researchers in the field of strategic management have traditionally applied this logic to established firms and explained how they can gain and sustain competitive advantages. Consistent with the upper-echelons perspectives (Hambrick and Mason 1984), the resourcebased view of firms emphasizes human resources in general and top management teams (TMTs) in particular as a major determinant of behaviors and outcomes of their organization. We expect stronger impacts of start-up teams on their firms than TMTs for the following reasons. As "owners and managers," start-up team members of a new venture will have a greater legitimacy in their decision-making process. It also takes awhile before start-up team members in new ventures begin to seek outsiders' advices, and thus as a consequence managerial initiatives and responsibilities are to be the exclusive domain of start-up team members for a certain period of time especially at the earlier stages. Even after their firms reach a later stage of developments, start-up team members tend to retain, rather than relinquish, their involvement in most of business functions (Ardichvili et al. 1998).

One of the most important sources of competitive advantages at start-up team level would be the experience that start-up team members have accumulated (McDougall, Shane, and Oviatt, 1994). Researchers in the 
field of international business based on firm internationalization theory (Johanson and Vahlne 1977) have regarded experience at the firm level as the most important determinant of international expansion pattern. Furthermore, experience has been perceived as a tacit knowledge and thus intangible resource difficult to learn (Eriksson, Johanson, and Majkgard 1997; Kogut and Zander 1993). Firm-level experiences would be greatly influenced by the level of experiences that start-up team members have accumulated before they establish their new firms. Following the arguments based on network theory and learning (Barkema, Bell, and Pennings 1996; Birley 1985; Coviello and Munro 1995; Dubini and Aldrich 1991; Johanson and Mattsson 1988), one may argue that new ventures led by start-up team members with higher levels of technical and business experience would feel fewer risks related to undertaking international expansion and thus more likely be involved in international expansion. Furthermore, the higher levels of technical and business experiences of start-up team members would help overcome the liability of foreignness (Shrader, Oviatt, and McDougall 2000), which may lead to higher performance in international expansion. This may be consistent with the arguments that initial human resources may cushion liabilities of newness and smallness and thus affect performance (Thakur 1998).

Proposition 5 (P5): The level of technical experience of start-up team members will be positively related to (1) the propensity to undertake international expansion and (2) the performance in international expansion.

Proposition 6 (P6): The level of business experience of start-up team members will be positively related to (1) the propensity to undertake international expansion and (2) the performance in international expansion.

\section{Methods}

This section discusses the analytical method to test the propositions and reports on the empirical results.

\section{Data}

To test the above propositions, this study used data taken from the data sets in a public archive, the University of Michigan Inter-University Consortium for Political and Social Research (ICPSR), and mainly from Minnesota New Firm Survey (Reynolds 1987) and Pennsylvania New Firm Survey (Reynolds, Freeman, and Oshana 1986). The two survey data provided a description of new firms established between 1979 and 1984 in the regions in all industry sectors. The two surveys used essentially the same survey instrument and thus were converged into a data set for the analysis in this study, resulting in a sample of 2,283 new ventures. ${ }^{2}$
Using the survey data provides several benefits. Probably the most important benefit of using the survey data is that respondents were those who had helped start the firm and who were still active in the management of the firms at the time of the survey. As individuals with responsibility for starting and managing the firm, they evaluated the liabilities of newness by answering questions related to start-up problems. Respondents were also asked to report company histories including sales, export, and asset history dating as far back as 1977 . The mid-1980s was a period of significant economic growth that enabled many new ventures to form, which made possible gathering of a large sample of new ventures (Shrader, Oviatt, McDougall 2000). By using the survey data, this study was also able to analyze the formation and growth of new ventures over multiple years.

\section{Measures}

The study examined the:

- propensity to undertake international expansion,

- performance in international expansion,

- product variables,

- strategy variables,

- start-up team variables, and

- control variables.

Propensity To Undertake International Expansion. International new ventures are usually defined as those that have obtained at least 10 percent (McDougall 1989) or 5 percent (Zahra, Ireland, and Hitt 2000) of their sales from foreign markets. To measure the propensity to undertake international expansion, this study used a more conservative criterion, whether the new venture generated at least 1 percent of their sales from international operations. This information was obtained from the new venture's sales and export history. A rating of 1 was assigned to the new venture that generated at least 1 percent of sales from international operations, and 0 otherwise.

Performance in International Expansion. In the research of new ventures, measuring performance is one of the biggest challenges due to the lack of traditional financial measures of performance that can be applied to new ventures (Bamford, Dean, and McDougall 1999; Cooper 1993). Related to this issue are a lack of guidance on and thus little consistency in performance measurement across studies (Brush and Vanderwerf 1992; Chandler and Jansen 1992; Murphy, Trailer, and Hill, 1996). The issues inherent in measuring new venture performance become more problematic when measuring it in the context of international expansion (Zahra, Ireland, and Hitt 2000). Nevertheless, data on sales growth were considered to measure performance because it is widely con- 
sidered a key indictor of new venture performance (Bloodgood, Sapienza, Almeida 1996; Brush 1995; Chandler and Hanks 1993; Zahra, Ireland, and Hitt 2000). This study followed Chandler and Hanks in their 1993 study and selected a three-year average of sales growth after international expansion as a proxy to measure performance of those new ventures that had undertaken international expansion. As noted in other studies (Bamford, Dean, and McDougall 1999; Eisenhardt and Schoonhoven 1990), however, the calculation of growth rates was somewhat problematic. Furthermore, exact sales figures were not available for all the years. Thus, following other studies (e.g., Anna et al. 2000; Chandler and Hanks 1993), this study relied on the total sales (in $\$ 1,000$ ) in the most recent year of those new ventures that had undertaken international expansion. ${ }^{3}$

Product Variables. The measure of product uniqueness was derived from answers to the question that asked the level of market niche for the new venture's products and services ("In terms of products and marketing, how much does your company have of a clear market niche for its products and services?"), which was expressed on a five-point scale ranging from "none" to "very much." The measure of product diversification was derived from answers to the question that asked the level of product diversification ("In terms of current business, what is the mix of sales among principal products, product lines, or services?"). Number 1 was assigned when firms generated sales from more than one product or service, and 0 otherwise.

Strategy Variables. Cost-oriented strategy was measured from answers to the question that asked the importance of "lower prices" as a competitive strategy for the new venture. The answers were expressed on a four-point scale ranging from "insignificant" to "critical." Similarly, technology-oriented strategy was measured from answers to the question that asked how important "utilize new/advanced technology" was as a competitive strategy for the new venture.

Start-up Team Variables. The level of technical experience of start-up team members was derived from answers to the question that asked the degree of start-up team members' technical experience ("At the present time, to what degree do company management, you, and other top executives have technical experience in key areas?"). The answer was expressed on a five-point scale ranging from "none" to "very much." Similarly, the level of business experience of start-up team members was derived from answers to the question that asked the degree of start-up team members' business experience ("At the present time, to what degree do company management, you, and other top executives have sufficiently well-rounded business experience?").
Control Variables. This study controlled for the potential effects of firm age and firm size. Firm age was measured by number of years a venture had been in existence, and firm size by number of employees. This study also included a dummy variable indicating whether the new venture belonged to a manufacturing (1) or service industry (0).

\section{Analysis}

Each of the propositions developed in this study deals with two aspects of international expansion: (1) propensity to undertake international expansion and (2) performance in international expansion. Thus, this study relied on two different analytical procedures to test each proposition. To test the propensity aspect (under which conditions new ventures were more likely to undertake international expansion) of each proposition, a logit model was used for all of the sample. A variable's positive coefficient indicates that the variable promotes international expansion. This study then used ordinary least squares (OLS) regressions analyses to test the performance aspect (under which conditions those ventures that had undertaken international expansion were more likely to achieve higher levels of performance) of each proposition, using only those new ventures that had undertaken international expansion.

\section{Results}

A general description of the sample in this study is as follows. Only 7 percent $(n=43)$ of the sample operating in manufacturing industries undertook international expansion within five years of founding. Similarly, it was only 4 percent $(n=67)$ for those in service industries. Taken together, only 110 new ventures (less than $5 \%$ of the sample) were involved in international expansion at their early stages. This is in sharp contrast with other studies that reported a much higher rate of new ventures' internationalization at their early stages. In the Shrader, Oviatt, and McDougall (2000) study, for example, about 41 percent of the sample were experiencing accelerated internationalization, undertaking international expansion within their sixth year of operation. The accelerated internationalization may reflect the sample characteristics. Their study "had a sample of successful firms" (p.1235) because one of the conditions that new ventures had to meet to be included in the study was that they had made initial public offerings (IPOs) of stock within six years of founding. It is not clear from the literature at which stage a new venture is not "new" anymore (Ostgaard and Birley 1996). Once new ventures have undertaken the IPOs, however, they might have already been successful in weathering rough times. Given the fact that the main focus of this study is on new ventures at their earlier stages in terms of not only ages but also success potentials, the relatively low rate of new ventures' internationalization would not be surprising. 
Exhibit 1 provides the descriptive statistics and correlations among the study variables. The correlation matrix does not exhibit any high correlation that may lead to multicollinearity problems. Exhibit 1 also shows that firm size has a significant relationship with both the propensity to undertake international expansion and the performance in international expansion. The negative relationship between the propensity and firm size is interesting. It implies that new ventures with smaller sizes are more likely to undertake international expansion. Once they begin to operate internationally, however, smaller new ventures seem to face a higher level of liabilities of foreignness, shown by the significant positive relationship between firm size and the performance. Another interesting correlation in Exhibit 1 is that between firm age and the propensity to undertake international expansion. The negative correlation is in line with, albeit not significant, the argument of structural inertia. According to organization theory literature (Hannan and Freeman 1984), structural inertia within a firm increases with its age, making older firms slower in responding to changes than younger firms. Given that international expansion is an important change to which firms need to respond, the negative relationship between firm age and propensity is as expected.

Exhibit 2 presents the estimation results of the logistic regression analyses on predicting new ventures' propensity to undertake international expansion. The results of Model 1 indicate that product uniqueness $(p<.01)$ is positively related to the international expansion propensity, which thus provides supports for P1. Product diversification, another product level variable, also has an expected, though not significant, relationship with the propensity.

The results of Model 2 disclose that new ventures with technology-oriented strategy $(p<.05)$ are more likely to undertake international expansion, which provides supports for P3. In contrast, cost-oriented strategy does not have a significant effect on the propensity even though it has an expected negative sign.

As shown in the results of Model 3, technology experience $(p<.05)$ has a positive effect on the propensity. Thus, P5 is supported. However, business experience, another start-up team variable, does not have a significant effect on the propensity.

Exhibit 3 presents results of the OLS regression analyses that test the performance aspect of each proposition. P1 states that product uniqueness as a variable at the product level would have a positive effect on the performance in international expansion. The results in Model 5, with product uniqueness $(p<.05)$, support P1. Product diversification ( $p<.01$ ), another variable at the product level, also has a positive effect on the performance as predicted by P2.

Among the strategy-level variables, cost-oriented strategy $(p<.05)$ has a negative effect on the performance, as shown in Model 6. This result thus supports P3. However, P4 predicting the positive effect of technology-oriented strategy on the performance is not supported.

Finally, the results in Model 7 indicate that technical experience as a variable at the start-up team level does not have a significant effect on the performance. Thus, P5 is not supported. However, business experience $(p<.01)$ shows a positive effect on the performance, which thus supports P6.

\section{Discussion and Conclusions}

As stated earlier, the ultimate goal of this study is to provide a more comprehensive view about international entrepreneurship by investigating the two important aspects of international entrepreneurship-the propensity to undertake international expansion and the performance in international expansion. Based on several theoretical arguments, this study has derived the propositions and empirically tested how the variables at different levels (product, strategy, and start-up team) may affect the propensity to undertake international expansion and the performance in international expansion by new ventures.

One of the interesting findings of this study is that among the six study variables, "product uniqueness" was the only variable that significantly affects both the propensity and the performance. According to the results, new ventures selling unique products are more likely to undertake international expansion and also achieve higher levels of performance. This result is consistent with the belief that product uniqueness, or the product's potential for niche markets, would be important for the growth and performance of new ventures (Gartner, Starr, and Bhat 1998; Mosakowski 1993). Other variables, however, failed to have a significant effect on both the propensity and performance of international entrepreneurship. More specifically, technology-oriented strategy and technical experience of startup team members had a statistically significant effect on the propensity but not on the performance; whereas costoriented strategy and business experience of start-up team members had a statistically significant effect on the performance but not on the propensity.

These results appear to have implications for both research and practice. Most researchers tend to treat the phenomena "propensity to undertake international expansion" and "performance in international expansion" as a single issue. This approach may reflect the core concept of "firm-specific advantage" that has been largely unquestioned in the field of international business as a tool to explain how firms can successfully compete in unfamiliar environments. Since the work of Hymer (1976), several scholars in the field of international business have identified many factors that attributed to firm-specific advan- 


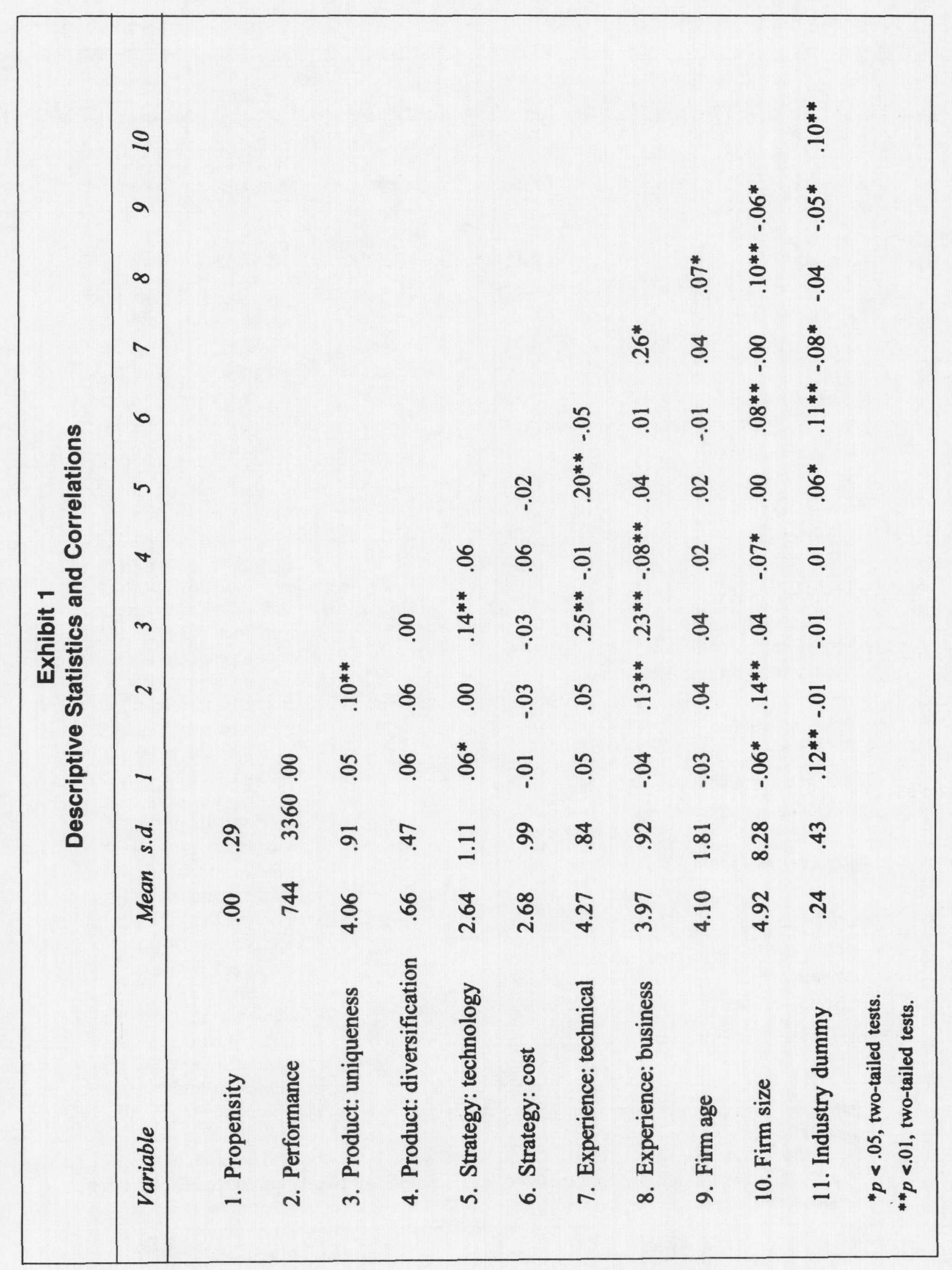




\section{Exhibit 2}

Results of Logistic Regression Analysis Predicting International Expansion Propensitya

Variable

Constant

Control variables

Firm age

Firm size

Industry dummy

Product level

Uniqueness

Diversification

Strategy level

Technology orientation

Cost orientation

Start-up team level

Technical experience

Business experience

\section{Model statistics}

$-2 \log$ likelihood

chi-square

Overall hit rate

Model 1 Model 2 Model $3 \quad$ Model 4

$\begin{array}{llll}-3.45^{* * *} & -2.23^{* * *} & -.27^{* *} & -3.56^{* *} \\ (.81) & (.49) & (.90) & (1.17)\end{array}$

$-.06$

$-.08$

$-.06$

(.07)

$-.10^{*}$

(.04)

-.06 (.06)

(.03)

$.81^{* *}$

(.27)

$-.04$

(.08)

$-.09 *$

(.04)

(.23)

$1.01^{* *}$

(.29)

(.28)

$.38^{* *}$

(.16)

$.37 *$

(.17)

.22

(.23)

(.30)

$.18^{*}$

.04

(.10)

(.13)

$-.07$

(.11)

$-.11$

(.15)

$.35^{*}$

(.18)

$-.15$

.26

(.19)

(.13)

$-.21$

(.15)

403.28

21.79**

652.26

456.88

389.42

$88.7 \%$

$21.19^{* *}$

$19.14^{* *}$

$24.51^{* *}$

$90.5 \%$

$89.2 \%$

$88.3 \%$

\footnotetext{
- Parameter estimates are shown; standard errors are in parentheses.

* $p<.05$.

$* * p<.01$.

*** $p<.001$ (one-tailed for hypothesized relationships and two-tailed for nonhypothesized relationships).
}

58 NEW ENGLAND JOURNAL OF ENTREPRENEURSHIP 


\section{Exhibit 3 \\ Results of OLS Regression Analyses Predicting Performance}

Variable

Control variables

Firm age

Firm size

Industry dummy

Product level

Uniqueness

Diversification

Strategy level

Technology orientation

Cost orientation

Start-up team level

Technical experience

Business experience

\section{Model statistics}

Model 5

$.10^{* *}$

(2.78)

$.23 * * *$

(6.20)

$-.02$

(-.57)

$.08^{*}$

(2.32)

.10 **

(2.73)
Model 7

$.09^{*}$

(2.51)

$.19 * * *$

(5.50)

(4.65)

$-.02$

(-.73)

$-.01$

$(-.14)$

Model 8

F

$11.67^{* * *}$

$-.01$

(-.19)

$-.04^{*}$

(-1.67)

(5.82)

$-.01$

$(-.26)$ 
tages that enable firms to undertake international expansion. The concept of firm-specific advantages has also been extended to explain the variance of performance in internationalizing firms (Buckley and Casson 1976; Caves 1982; Dunning 1977; Hennart 1982). Thus, firm-specific advantages have long been perceived as a determinant of both propensity and performance in international expansion. From a practical point of view, many entrepreneurs or start-up team members may be overconfident in the success of their ventures, experiencing "entrepreneurial euphoria" (Cooper, Woo, and Dunkelberg 1988), and such overconfidence may cause them to view international expansion as a viable strategic option and thus undertake international expansion even before they are ready.

As this study's findings indicate, however, undertaking international expansion and reaping from the international expansion are two different phases in international entrepreneurship. Unlike MNCs and SMEs with a long history of operation in not only domestic but also foreign markets, new ventures that enter into international markets at very early stages, if not from inception, may have little time to prepare for the unprecedented operation. Preparedness and learning from previous international experience are required for both SMEs and MNCs to reduce the risks of becoming an international player (Chen and Martin, 2001; Mitchell, Shaver, and Yeung 1992). Such preparedness and learning would be most critical for international new ventures that may face the liabilities of not only "foreignness" but also "newness."

Thus, treating propensity and performance related to international entrepreneurship as separate issues would be highly required from both theoretical and practical points of views. As this study found, for example, start-up team members with higher levels of technical experience are more likely to undertake international expansion. But it is the level of business experience that actually has a positive relationship with the performance in international expansion. This study also found that new ventures with cost-leadership strategy are less likely to reap high performance in international expansion. It is in contrast with the reports that showed feasibility of pursuing cost-leadership competitive strategies by established firms (Lawrence and Sloan 1992; Roush 1993; Weiner 1987; Zellner 2001).

This study's findings also confirm that the size of a new venture matters. However, it was found to matter differently. As the results in Exhibit 2 indicate, firm size had a significant negative effect on the propensity in all the models (Models 1-4), indicating that smaller new ventures are more likely to undertake international expansion. Then, how about the effect of firm size on the performance? Does it still matter? Yes, but in a different way. As the results in Exhibit 3 show, firm size had a significant positive effect on the performance in all the models (Models 5-8). Combining these results, one may conclude that larger new ventures are in a better position to overcome liabilities of foreignness even though they are more reluctant to be involved in international expansion than smaller ones. These results, coupled with the significant positive effect of firm age on the performance, seem to indicate that liability of foreignness may be reduced significantly as new ventures become bigger and older. This is an interesting result, implying that new ventures can reduce not only the liability of newness, but also the liability of foreignness as they become older probably through learning. This conclusion is highly speculative and requires additional research. While recent research has investigated how established firms' performances in international operations are affected by length of operation in a host country (e.g., Luo 1999; Luo and Peng 1999) and prior international experience of the parent company (e.g., Millington and Bayliss 1997), no published study has yet examined the performance impact of organizational learning within the context of earlier stages of new ventures.

There are several limitations in this study. First, the findings of this study were based on a sample limited to new ventures in specific regions in the United States. Thus, the findings should not be generalized without further replication in a different context. New ventures in other regions of the country or in foreign countries should be surveyed to find out any similarities and differences in their internationalization pattern and performance (McGrath, MacMillan, and Scheinberg 1992). Second, the findings of this study were based on a small number of valid cases due to the very low rate of international expansion among the sample firms. The probability of finding a statistically significant variable is relatively low when the number of valid cases is very small. Further research with more valid cases of new ventures' international expansion should be conducted to investigate the validity of the findings from this study. The small number of valid cases also precluded more sophisticated, separated analyses of industry effects. Investigating how industry-related characteristics affect new ventures' international expansion would be a fertile area for future research. There is also a need for improved measure of the study variables. Due to the limited number of questions in the survey data that can be used as a proxy for the study variables, this study had to rely on single-item scales. In addition, this study could not consider factors at the host country level because the data sets used reported only the combined percentages of foreign sales, with no separate data regarding host country names and the percentage of sales from those countries. Variations in terms of social conditions and economic developments across host countries, for example, might affect the propensity and the performance (McDougall and Oviatt, 1997), and thus future research might choose to investigate host-country characteristics for a better understanding of international entrepreneurship. Finally, as this was a correlational study, one 
should not infer causality from the present findings. It would be desirable for future research to use a longitudinal research design to assess causality.

Despite these limitations, the present findings in this exploratory study provide a foundation for more rigorous research on international entrepreneurship. How to gain and sustain competitive advantages is important for firms regardless of firm size or firm age. The significant contribution of new ventures to job creation and revenue generation (Reynolds and White 1997; Wennekers and Thurik 1999) and the reality that more than half of new ventures fail within their first four years (Timmons 1999), however, make the research on new ventures more meaningful. The emergence of "accelerated internationalization" (Shrader, Oviatt, and McDougall 2000) and "born-global" (Hordes, Clancy, and Baddaley 1995; Knight and Cavusgil 1996) also requires researchers to explore international entrepreneurship issues in a more systematic way. Furthermore, given the possibility that new ventures' early internationalization would be more widespread in the future (Madsen and Servais 1997), it is imperative that researchers pay more attention to the issue than they did in the past.

International entrepreneurship is at the intersection of the two research fields-international business and entrepreneurship-requiring interdisciplinary approach. However, the fields' research foci have not yet been extended enough to incorporate international entrepreneurship into their main research streams. As a result, the issue of international expansion by new ventures remains empirically underresearched in both fields and research findings about international entrepreneurship are still in relative scarcity. This study may provide a foundation that future empirical researchers from both fields can use to further explore the important aspects of international entrepreneurship-causes and consequences-in international expansion launched by new ventures.

\section{Endnotes}

1. In this article, the terms "international expansion" and "internationalization" are used interchangeably.

2. The converged data set could have produced a sample of more than 2,283 new ventures, but many cases were excluded because they did not provide basic information necessary for the analyses in this study.

3. Alternatively, this used a certain year, for example in 1985, to derive a snapshot of the performance, which showed similar results.

4. In the survey, number 1 indicated "very much," 2 "quite a bit," 3 "a moderate amount," 4 "little," and 5 "none." For the convenience of interpreting the result, this study recoded so that number 5 indicates "very much," 4 "quite a bit" and so forth. Thus, the higher the number, the more unique the products and service. This study did the same for other measurements where necessary.

5. In the survey, number 1 indicated "critical," 2 "important," 3 "marginal," and 4 "insignificant." For the convenience of interpreting the result, this study recoded so that number 4 indicates "critical," 3 "important" and so forth. Thus, the higher the number, the more important aspects of the company strategy. This study did the same for other measurements where necessary.

\section{References}

Allen, K. R. 1999. Launching new ventures: An entrepreneurial approach. Houghton Mifflin Company.

Anna, Alexandra, G. N. Chandler, E. Jansen, and N. P. Mero. 2000. Women business owners in traditional and non-traditional industries. Journal of Business Venturing 15: 279-303.

Ardichvili, A., G. Harmon, R. N. Cardozo, P. D Reynolds, and M. L. Williams. 1998. The new venture growth: Functional differentiation and the need for human resource development interventions. Human Resource Development Quarterly 9, 1: 55-70.

Bamford, C. E., T. J. Dean, and P. P. McDougall. 1999. An examination of the impact of initial founding conditions and decisions upon the performance of new bank start-ups. Journal of Business Venturing 15: 253-277. 
Barkema, H. G., J. H. Bell, and J. M. Pennings. 1996. Foreign entry, cultural barriers, and learning. Strategic Management Journal 17: 151-166.

Barney, J. B. 1991. Firm resources and sustainable competitive advantage. Journal of Management 17: 99-120.

Begley, T. M., and D. P. Boyd. 1987. Psychological characteristics associated with performance in entrepreneurial firms and smaller businesses. Journal of Business Venturing 2, 1: 79-93.

Berra, L., L. Piatti, and G. Vitali. 1995. The internationalization process in the small and medium sized firms: A case study on the Italian clothing industry. Small Business Economics 7, 1: 67-75.

Birley, S. 1985. The role of networks in the entrepreneurial process. Journal of Business Venturing 1: 107-117.

Bloodgood, J. M., H. J. Sapienza, and J. G. Almeida. 1996. The internationalization of new high-potential U.S. ventures: Antecedents and outcomes. Entrepreneurship Theory and Practice 20, 4: 61-76.

Brush, C. G. 1995. International entrepreneurship: The effects of firm age on motives of internationalization. New York: Garland.

Brush, C. G., and P. A. Vanderwerf. 1992. A comparison of methods and sources for obtaining estimates of new venture performance. Journal of Business Venturing 7: 157-170.

Buckley, P.J., and M. C. Casson, M. C. 1976. The future of the multinational enterprise. London: MacMillan.

Caves, R. E. 1982. Multinational enterprise and economic analysis. New York: Cambridge University Press.

Chandler, G. N., and S. H. Hanks. 1993. Measuring the performance of emerging businesses: A validation study. Journal of Business Venturing 8: 391-408.

Chandler, G. N., and E. Jansen. 1992. The founder's self-assessed competence and venture performance. Journal of Business Venturing 7: 223-236.

Chen, R., and M. J. Martin. 2001. Foreign expansion of small firms: The impact of domestic alternatives and prior foreign business involvement. Journal of Business Venturing 16: 557-574.

Chetty, S., and D. B. Holm. 2000. Internationalization of small to medium-sized manufacturing firms: A network approach. International Business Review 9: 77-93.

Cooper, A. C. 1993. Challenges in predicting new venture performance. Journal of Business Venturing 8, 3: 241-253.

Cooper, A. C., C. Y. Woo, and W. C. Dunkelberg. 1988. Entrepreneurs' perceived chance of success. Journal of Business Venturing 3, 3: 97-108.

Coviello, N. E., and H. J. Munro, H. J. 1995. Growing the entrepreneurial firm: Networking for international market development. European Journal of Marketing 29, 7: 49-61.

Covin, J. G. 1991. Entrepreneurial versus conservative firms: A comparison of strategies and performance. Journal of Management Studies 28, 5: 437-462.

Dubini, P., and H. Aldrich. 1991. Personal and extended networks are central to the entrepreneurial process. Journal of Business Venturing 6: 306-313. 
Dunning, J. H. 1977. Trade, location of economic activity and the MNE: A search for an eclectic approach. In B. Ohlin, P. O. Hesselborn, and P. M. Wijkman, eds., The international allocation of economic activity. New York: Holmes \& Meier.

Eisenhardt, K. M., and C. B. Schoonhoven. 1990. Organizational growth: Linking founding team, strategy, environment, and growth among U.S. semiconductor ventures, 1978-1988. Administrative Science Quarterly 35: 504-529

Eriksson, K., J. Johanson, and A. Majkgard. 1997. Experiential knowledge and cost in the internationalization process. Journal of International Business Studies: 337-360.

Gankema, H. G. J., H. R. Snuif, and P. Zwart. 2000. The internationalization process of small and medium-sized enterprises: An evaluation of stage theory. Journal of Small Business Management: 15-27.

Gartner, W. B., J. A. Starr, and S. Bhat. 1998. Predicting new venture survival: An analysis of "Anatomy of a startup." Cases from Inc. Magazine. Journal of Business Venturing 14: 215-232.

Ghoshal, S., and C. A. Bartlett. 1990. The multinational corporation as an interorganizational network. Academy of Management Review 15, 4: 603-625.

Ghoshal, S., and N. Nohria. 1989. Internal differentiation within multinational corporations. Strategic Management Journal 10: 323-337.

Hambrick, D. C., and P. A. Mason. 1984. Upper Echelons: The organization as a reflection of its top managers. Academy of Management Review 9, 2: 193-207.

Hannan, M. T., and J. Freeman. 1984. Structural inertia and organizational change. American Sociological Review 49: 149-164.

Hennart, J. F. 1982. A theory of multinational enterprise. Ann Arbor: University of Michigan Press.

Hitt, M. A., R. Hoskisson, and H. Kim. 1997. International diversification: Effects on innovation and firm performance in product-diversified firms. Academy of Management Journal 40, 4: 767-798.

Hood, N., and S. Young. 1979. The economics of multinational enterprise. New York: Longman.

Hordes, M. W, A. Clancy, and J. Baddaley. 1995. A primer for global start-ups. The Academy of Management Executive 9, 2: 7-12.

Hymer, S. 1976. The international operations of national firms: A study of direct foreign investment. Cambridge, Mass: MIT Press.

Johanson, J., and L. G. Mattsson. 1988. Internationalization in industrial systems-A network approach. In N. Hood and J. E. Vahlne, eds., Strategies in global competition. London: Croom Helm.

Johanson, J., and J. Vahine, J. 1977. The internationalization process of the firm-A model of knowledge development and increasing foreign market commitments. Journal of International Business Studies 23-32.

Karagozoglu, N., and M. Lindell. 1998. Internationalization of small and medium-sized technology-based firms: An exploratory study. Journal of Small Business Management 36, 1: 44-59.

Kazanjian, R. K. 1988. Relation of dominant problems to stages of growth in technology-based new ventures. Academy of Management Journal 31: 257-279. 
Knight, G. A., and S. T. Cavusgil. 1996. The born global firm: A challenge to traditional internationalization theory. Advances in International Marketing 8: 11-26.

Kogut, B., and U. Zander. 1993. Knowledge of the firm and the evolutionary theory of the multinational corporation. Journal of International Business Studies 625-645.

Lawrence, J., and P. Sloan. 1992. P\&G plans big new Ivory push. Advertising Age (November 23): 12.

Luo, Y. 1999. Time-based experience and international expansion: The case of an emerging Economy. Journal of Management Studies 36, 4: 505-534.

Luo, Y., and M. W. Peng. 1999. Learning to compete in a transition economy: Experience, environment, and performance. Journal of International Business Studies 30, 2: 269-296.

Madsen, T. K., and P. Servais. 1997. The internationalization of born globals: An evolutionary process? International Business Review 6, 6: 561-583.

McDougall, P. P. 1989. International versus domestic entrepreneurship: New venture strategies in young ventures. Journal of Business Venturing 4:387-399.

McDougall, P. P., and B. M. Oviatt. 1997. International entrepreneurship literature in the 1990s and directions for future research. In D. L. Sexton and Raymond W. Smilor, eds., Entrepreneurship 2000. Upstart Publishing Company.

McDougall, P. P., S. Shane, and B. M. Oviatt. 1994. Explaining the formation of international new ventures: The limits of theories from international business research. Journal of Business Venturing 9: 469-87.

McGrath, R. G., I. C. MacMillan, and S. Scheinberg. 1992. Elitists, risk-takers, and rugged individualists? An exploratory analysis of cultural differences between entrepreneurs and non-entrepreneurs. Journal of Business Venturing 7: 115-135.

Millington, A. I., and B. T. Bayliss. 1997. The strategy of internationalization and the success of UK transnational manufacturing operations in the European Union. Management International Review 37, 3: 199-221.

Mitchell, W., J. M. Shaver, and B. Yeung. 1992. Getting there in a global industry: Impacts on performance. Strategic Management Journal 13, 6: 419-432.

Mosakowski, E. 1993. A resource-based perspective on the dynamic strategy-performance relationship: An empirical examination of the focus and differentiation strategies in entrepreneurial firms. Journal of Management 19, 4: $819-839$.

Murphy, G. B., J. W. Trailer, and R. C. Hill. 1996. Measuring performance in entrepreneurship research. Journal of Business Research 36: 15-23.

Ostgaard, T. A., and S. Birley. 1996. New venture growth and personal networks. Journal of Business Research 36: 37-50.

Oviatt, B. M., and P. P. McDougall, P.P. 1997. Challenges for internationalization process theory: The case of international new ventures. Management International Review, Special issue: 85-99.

Porter, M. E. 1980. Competitive strategy. New York: Free Press.

Reynolds, P. D. 1987. Minnesota new firm survey [computer file]. Minneapolis, MN: P.D. Reynolds, University of Minnesota, Dept. of Sociology [producer]. ICPSR version. Ann Arbor, MI: Inter-university consortium for political and social research [distributor], 1995. 
Reynolds, P. D., S. Freeman, and L. Oshana, L. 1986. Pennsylvania new firm survey, 1979-1984 [computer file]. ICPSR version. Philadelphia, PA: P.D. Reynolds, University of Pennsylvania, Wharton School [producer], 1995. Ann Arbor, MI: Inter-university consortium for political and social research [distributor], 1995.

Reynolds, P. D. , and S. B. White. 1997. The entrepreneurial process. Greenwich, CT: Quorum Books.

Robinson, K. C. 1998. An examination of the influence of industry structure on eight alternative measures of new venture performance for high potential independent new ventures. Journal of Business Venturing 14: 165-187.

Roush, C. 1993. At Timex, they're positively glowing. Business Week (July 12): 141

Rumelt, R. 1984. Towards a strategic theory of the firm. In R. Lamb, ed., Competitive strategic management. Englewood Cliffs, NJ: Prentice-Hall.

Sandberg, W., and C. Hofer. 1987. Improving new venture performance: The role of strategy, industry structure, and the entrepreneur. Journal of Business Venturing 2: 5-28

Scherer, F. M. 1980. Industrial market structure and economic performance. Boston: Houghton Mifflin.

Shrader, R. C., B. M. Oviatt, and P. P. McDougall. 2000. How new ventures exploit trade-offs among international risk factors: Lessons for the accelerated internationalization of the 21 st century. Academy of Management Journal 43, 6: 1227-1247.

Stewart, W. H., W. Watson, J. C. Carland, and J.W. Carland, 1998. A proclivity for entrepreneurship: A comparison of entrepreneurs, small business owners, and corporate managers. Journal of Business Venturing 14: 189-214.

Stinchcombe, A. 1965. Social structure and organizations. In J.G. March, ed., Handbook of organizations, 142-193. Chicago: Rand McNally.

Tallman, S., and J. Li. 1996. Effects of international diversity and product diversity on the performance of multinational firms. Academy of Management Journal 39: 179-196.

Terpstra, D. E., and P. D. Olson. 1993. Entrepreneurial start-up and growth: A classification of problems. Entrepreneurship: Theory and Practice 17, 3: 5-20.

Thakur, S. P. 1998. Size of investment, opportunity choice and human resources in new venture growth: Some typologies. Journal of Business Venturing 14: 283-309.

Timmons, J. A. 1999. New venture creation: Entrepreneurship for the 21st century. Homewood, III: Irwin.

Tyebjee, T.T., and A. V. Bruno. 1984. A Model of venture capitalist investment activity. Management Science 30, 9: $1051-1067$.

Vernon, R. 1966. International investment and international trade in the product cycle. Quarterly Journal of Economics. 80: 190-297.

Vernon, R. 1979. The product cycle hypothesis in a new international environment. Oxford Bulletin of Economics and Statistics. 255-267.

Weiner, S. 1987. The road most travels. Forbes (October 19): 60-64.

Wennekers, S., and R. Thurik, R. 1999. Linking entrepreneurship and economic growth. Small Business Economics 13: $27-55$.

Wernerfelt, B. 1984. A resource-based view of the firm. Strategic Management Journal 5: 171-180. 
Wortman, M. S. 1986. A unified framework, research typologies, and research prospectuses for the interface between entrepreneurship and small business. In D. L. Sexton and R.W. Smilor, eds., The art and science of entrepreneurship. Cambridge, MA: Ballinger, pp. 273-331.

Wright, R. W., and D. Ricks. 1994. Trends in international business research: Twenty-five years later. Journal of International Business Studies 25: 687-701.

Zafarullah, M., M. Ali, and S. Young. 1998. The internationalization of the small firm in developing countriesExploratory research from Pakistan. Journal of Global Marketing 11, 3: 21-40.

Zaheer, S. 1995. Overcoming the liability of foreignness. Academy of Management Journal 38, 2: 341-363.

Zahra, S. A., R. D. Ireland, and M. A. Hitt. 2000. International expansion by new venture firms: International diversity, mode of market entry, technological learning and performance. Academy of Management Journal 43: 925-950.

Zellner, W. 2001. How well does Wal-Mart travel? Business Week (September 3).

\section{Acknowledgment}

This research was supported by a Korean University grant.

\section{NESE}

Jay Hyuk Rhee (jayrhee@korea.ac.kr) is an assistant professor of international business and strategic management at Korea University. He received his Ph.D. from Ohio State University. His research interests include entrepreneurship, E-business, and international expansion process. Dr. Rhee has worked as education director of the Korean E-Commercialization Institute $(\mathrm{KECl})$ at San Jose, California. 